\title{
Antusiasme Masyarakat dalam Program Mengajar dari Rumah (MDR) di Era Pandemi di Desa Penedagandor, Lombok Timur
}

\author{
Laily Fitriani Mulyani ${ }^{1}$ \\ Universitas Mataram
}

\begin{abstract}
One of the impacts of Covid-19 is in the field of education. The impact of Covid-19 is very felt by some people in rural areas who experience signal difficulties in their areas, high (expensive) internet quota, unequal internet quota assistance for parents of guardians, unfamiliar parents with internet, parents It is difficult to teach their children because many guardians of students in rural areas have dropped out of school, so the government has to make quick and accurate policies. One of the policies implemented by the Ministry of Education and Culture is to support the Teaching from Home Program (TFH). This activity involved 35 students who took part in the teaching and learning process and parents who gave permission for their child's participation. This study used a survey method and data collection using a questionnaire that has been distributed after the teaching and learning activities ended. The results of this questionnaire were analyzed using descriptive statistics using the SPSS computer program. Based on the results of the research that has been carried out, it is concluded that the activities of the Home Teaching Program have received positive responses and the community is very enthusiastic about this activity.
\end{abstract}

Keywords : Covid-19, TFH, Enthusiasts, Volunteer

\begin{abstract}
Abstrak
Salah satu dampak dari covid-19 adalah di bidang pendidikan. Dampak dari covid-19 ini sangat dirasakan oleh beberapa kalangan di pedesaan yang mengalami susahnya signal di wilayahnya, kuota internet yang (mahal) tinggi, tidak meratanya bantuan kuota internet untuk orang tua wali murid, tidak familiarnya orang tua wali murid dengan internet, orang tua kesulitan mengajar anaknya dikarenakan banyak wali murid di wilayah pedesaan yang putus sekolah, sehingga pemerintah harus mengambil kebijakan yang cepat dan tepat. Salah satu kebijakan yang dilakukan oleh Kementerian Pendidikan dan Kebudayaan adalah mendukung kegiatan Program Mengajar dari Rumah (MDR). Kegiatan ini melibatkan 35 siswa yang mengikuti proses belajar mengajar dan orang tua siswa yang memberikan izin atas keikutsertaan anak mereka. Penelitian ini menggunakan metode survei dan pengumpulan data menggunakan kuesioner (angket) yang telah disebar setelah kegiatan proses belajar mengajar ini berakhir. Hasil kuesioner ini dianalisis menggunakan statistik deskriptif dengan menggunakan program komputer SPSS. Berdasarkan hasil penelitian yang telah dilakukan disimpulkan bahwa kegiatan Program Mengajar dari Rumah ini mendapatkan respon yang positif dan masyarakat sangat antusias terhadap kegiatan ini.
\end{abstract}

Kata Kunci : Covid-19, MDR, Antusias, Relawan

\footnotetext{
${ }^{1}$ lailyfitriani@unram.ac.id
} 


\section{Pendahuluan}

Sebagaimana kita ketahui, saat ini dunia sedang berduka diakibatkan oleh bencana pandemi yang melanda. Indonesia juga terkena dampak dari pandemi yang melanda mulai dari awal tahun 2019 tersebut. Dampak yang diakibatkan hampir dari semua sektor mulai dari sektor perekonomian hingga ke sektor pendidikan. Apabila pemerintah tidak segera mengambil kebijakan yang tepat, Indonesia akan mengalami penurunan kualitas yang drastis. Kasus Covid-19 mengalami fluktuasi presentasi setiap harinya bahkan setiap jam nya tercatat pergerakan dari kasus tersebut. Di awal bulan November tahun 2020, kasus covid-19 di wilayah Nusa Tenggara Barat sebagai berikut: Kota Mataram terdapat 1277 kasus, Kabupaten Lombok Barat berjumlah 721 kasus, Kabupaten Lombok Tengah 260 kasus, Kabupaten Lombok Utara 126 kasus, Kabupaten Lombok Timur berjumlah 538 kasus, Kabupaten Sumbawa Barat 61 kasus, Kabupaten Sumbawa 258 kasus, Kabupaten Dompu terdapat 229 kasus, Kabupaten Bima 165 kasus, Kota Bima 241 kasus, Warga Negara Asing sejumlah 5 kasus dan di luar provinsi terdapat 111 kasus (DISKOMINFOTIK NTB, 2020).

Berdasarkan jumlah kasus covid yang terdapat di wilayah Nusa Tenggara Barat, masyarakat tetap dihimbau untuk tetap mengikuti protokol kesehatan. Kegiatan yang berkaitan dengan 'berkumpul banyak orang' tidak disarankan untuk dilakukan. Termasuk juga masih dilakukannya belajar dari rumah oleh beberapa sekolah-sekolah di NTB. Akan tetapi, banyak kendala yang terjadi selama dilakukannya belajar dari rumah tersebut, terlebih lagi di wilayah-wilayah pedesaan. Hal itu disebabkan karena beberapa faktor, diantaranya: susahnya sinyal di wilayah pedesaan, kuota internet yang tinggi, tidak meratanya bantuan kuota internet untuk orang tua wali murid, tidak familiarnya orang tua wali murid dengan internet, dan orang tua kesulitan mengajar anaknya dikarenakan banyak wali murid di wilayah pedesaan yang putus sekolah dan sebagainya.

Karena beberapa faktor itulah, pemerintah mencoba untuk menjalankan program "Mengajar dari Rumah". Dimana volunteer nya bisa dari kalangan siapa saja yang memiliki komitmen untuk membantu meningkatkan kualitas anak bangsa dalam bidang pendidikan di setiap wilayah, terutama di wilayah pedesaan. Kegiatan ini diperlukan untuk meningkatkan kualitas belajar siswa di era pandemi. Selain itu, tujuan dari kegiatan ini adalah melihat respon dan antusiasme masyarakat dalam program mengajar dari rumah. Nantinya sekolah, siswa serta orang tua murid tidak perlu khawatir akan kualitas dari setiap murid di area pandemi dan tujuan dari peningkatan kualitas mutu belajar murid dapat tercapai. Kegiatan ini merupakan gagasan dari kelompok alumni yang pernah mendapatkan beasiswa dari pemerintah dan pemerintah mendukung kegiatan positif ini. Kegiatan ini baru pertama kali dilakukan di Indonesia, mengingat pandemi melanda dunia yang terjadi pada awal tahun 2019 menjadi salah satu faktor muncul gagasan yang bermanfaat ini. 


\section{Metode Penelitian}

Lokasi penelitian di Desa Penedagandor, Kecamatan Labuhan Haji, Kabupaten Lombok Timur, Nusa Tenggara Barat. Penelitian ini dilaksanakan selama 30 hari mulai tanggal 14 Agustus 14 September 2020. Metode yang digunakan dalam penelitian ini yaitu metode survei dan pengumpulan data menggunakan angket (kuesioner). Analisis menggunakan statistik deskriptif dengan menggunakan program komputer SPSS, yaitu merupakan software powerfull yang digunakan untuk analisis statistik. Metode statistik diawali dengan pengumpulan data, dimana data yang dikumpulkan adalah data kuesioner, form, data sekunder kemudian dilakukan pengolahan data. Setelah itu dilakukan penyajian data menggunakan text, tabel, dan diagram.

Metode penelitian survey adalah penelitian yang sumber data dan informasi utamanya diperoleh dari responden sebagai sampel penelitian dengan menggunakan kuesioner atau angket sebagai instrumen pengumpulan data (Harim, 2020). Kemudian, dalam penelitian ini dilakukan juga metode penelitian kualititaf, dimana metode ini merupakan metode yang mendeskripsikan suatu gejala sosial tertentu (Slamet, 2006). Alat dan bahan yang digunakan saat penelitian adalah papan tulis, buku tulis, bolpoint, kertas, pensil warna/crayon, meja, kursi, daftar hadir siswa, kamera dokumentasi, lembar kuesioner. Variabel yang diukur adalah jenis kelamin, tingkat pendidikan, usia dan tingkat kepuasan dari siswa dan orang tua siswa yang ikut berpartisipasi dalam kegiatan MDR.

\section{Hasil dan Pembahasan}

\section{Pengertian Program Mengajar dari Rumah}

Kementerian Pendidikan dan Kebudayaan (Kemendikbud) meluncurkan Program Mengajar Dari Rumah (MDR). Program ini mengajak relawan yang tersebar di seluruh Indonesia untuk berkontribusi secara sukarela dalam membantu kegiatan belajar mengajar murid PAUD hingga SMP yang mengalami kendala dalam pelaksanaan metode Pembelajaran Jarak Jauh (PJJ) (Kasih, 2020). Akan tetapi, dalam penelitian penulis, siswa yang direkrut dari TK hingga kelas 6 SD. Hal tersebut dilakukan dikarenakan peminat dan kebutuhan dari siswa TK hingga kelas 6 SD lebih tinggi dibandingkan dengan siswa jenjang SMP. Pada kegiatan ini, Kemendikbud memanfaatkan program ini untuk mengedukasi masyarakat terkait pencegahan penularan Covid-19. Menteri Pendidikan dan Kebudayaan Nadiem Makarim mengatakan dalam Opening Batch I Mengajar dari Rumah yang disiarkan channel Youtube Ditjen Dikti "Pada angkatan ini, rekan-rekan akan membawa misi dari satuan tugas Covid-19 untuk mengubah perilaku. Mengingatkan masyarakat untuk menjalankan protokol 3M yaitu memakai masker, menjaga jarak dan mencuci tangan dengan sabun". Bapak Menteri Pendidikan dan Kebudayaan menyatakan dukungannya terhadap kepedulian relawan yang ingin membantu masyarakat dalam meningkatkan kualitas pendidikan (Fahlevi, 2020). 
Antusiasme Masyarakat dalam Program Mengajar dari Rumah (MDR) di Era Pandemi di Desa Penedagandor, Lombok Timur

\section{Proses Kegiatan Program Mengajar dari Rumah}

Pada program Mengajar dari Rumah (MDR) tetap mematuhi protokol kesehatan, sehingga dalam proses belajar mengajar tidak lebih dari 10 orang. Para siswa bergantian mengikuti dalam proses belajar mengajar dan disesuaikan waktunya. Siswa yang turut ikut berpartisipasi dalam program ini berjumlah 35 orang dengan rentang pendidikan mulai dari TK (Taman Kanak - kanak) hingga kelas 6 SD (Sekolah Dasar). Daftar tabel siswa yang ikut berpartisipasi dalam program dapat dilihat pada Tabel 1.

Tabel 1. Daftar Siswa yang Ikut berpartisipasi dalam Program

\begin{tabular}{|c|c|c|c|c|c|c|c|c|c|c|}
\hline \multirow[t]{2}{*}{ No } & \multirow{2}{*}{$\begin{array}{l}\text { Nama } \\
\text { Siswa }\end{array}$} & \multirow{2}{*}{$\begin{array}{c}\text { Jenis } \\
\text { Kelamin }\end{array}$} & \multicolumn{7}{|c|}{ Pendidikan } & \multirow{2}{*}{$\begin{array}{l}\text { Usia } \\
\text { (Thn) }\end{array}$} \\
\hline & & & TK & $1 \mathrm{SD}$ & $2 \mathrm{SD}$ & $3 \mathrm{SD}$ & $4 \mathrm{SD}$ & $5 \mathrm{SD}$ & $6 \mathrm{SD}$ & \\
\hline 1 & Iqbal & $\mathrm{L}$ & $\sqrt{ }$ & & & & & & & 6 \\
\hline 2 & Zahira & $\mathrm{P}$ & & $\sqrt{ }$ & & & & & & 7 \\
\hline 3 & Alfan & $\mathrm{L}$ & & & & $\sqrt{ }$ & & & & 9 \\
\hline 4 & Andin & $\mathrm{P}$ & & & & & $\sqrt{ }$ & & & 10 \\
\hline 5 & Anggun & $\mathrm{P}$ & & & & & & $\sqrt{ }$ & & 11 \\
\hline 6 & Aulia & $\mathrm{P}$ & & & & & & & $\sqrt{ }$ & 12 \\
\hline 7 & Ilham & $\mathrm{P}$ & & & $\sqrt{ }$ & & & & & 8 \\
\hline 8 & Dimas & $\mathrm{L}$ & & & $\sqrt{ }$ & & & & & 8 \\
\hline 9 & Rara & $\mathrm{L}$ & $\sqrt{ }$ & & & & & & & 6 \\
\hline 10 & Paku & $\mathrm{L}$ & & & & & & & $\sqrt{ }$ & 12 \\
\hline 11 & Pasha & $\mathrm{L}$ & 4 & & & & & & $\sqrt{ }$ & 12 \\
\hline 12 & Zizi & $\mathrm{P}$ & $\sqrt{ }$ & & & & & & & 6 \\
\hline 13 & Hanum & $\mathrm{P}$ & $\sqrt{ }$ & & & & & & & 4 \\
\hline 14 & Budi & $\mathrm{L}$ & & $\sqrt{ }$ & & & & & & 7 \\
\hline 15 & Nita & $\mathrm{P}$ & & & $\sqrt{ }$ & & & & & 8 \\
\hline 16 & Diah & $\mathrm{P}$ & & & & $\sqrt{ }$ & & & & 9 \\
\hline 17 & Dwi & $\mathrm{P}$ & & & & $\sqrt{ }$ & & & & 9 \\
\hline 18 & Eka & $\mathrm{P}$ & & & & & $\sqrt{ }$ & & & 10 \\
\hline 19 & Roni & $\mathrm{L}$ & & & & & & $\sqrt{ }$ & & 11 \\
\hline 20 & Dio & $\mathrm{L}$ & & & & & $\sqrt{ }$ & & & 10 \\
\hline 21 & Aurel & $\mathrm{P}$ & & & & & & & $\sqrt{ }$ & 12 \\
\hline 22 & Mita & $P$ & & & & & & & $\sqrt{ }$ & 12 \\
\hline 23 & Bagas & $\mathrm{L}$ & & & & & & $\sqrt{ }$ & & 10 \\
\hline 24 & Udin & $\mathrm{L}$ & & & & $\sqrt{ }$ & & & & 9 \\
\hline 25 & Putri & $P$ & & & $\sqrt{ }$ & & & & & 8 \\
\hline 26 & Kadri & $\mathrm{L}$ & & $\sqrt{ }$ & & & & & & 7 \\
\hline 27 & Sera & $\mathrm{P}$ & & & & $\sqrt{ }$ & & & & 9 \\
\hline 28 & Diki & $\mathrm{L}$ & & & $\sqrt{ }$ & & & & & 8 \\
\hline 29 & Khairul & $\mathrm{L}$ & & $\sqrt{ }$ & & & & & & 8 \\
\hline 30 & Mimi & $\mathrm{P}$ & $\sqrt{ }$ & & & & & & & 5 \\
\hline 31 & Dina & $\mathrm{P}$ & & $\sqrt{ }$ & & & & & & 7 \\
\hline 32 & Rina & $\mathrm{P}$ & & & & $\sqrt{ }$ & & & & 9 \\
\hline 33 & Nila & $\mathrm{P}$ & & & & & $\sqrt{ }$ & & & 10 \\
\hline 34 & Opan & $\mathrm{L}$ & & $\sqrt{ }$ & & & & & & 7 \\
\hline 35 & Ipa & $\mathrm{P}$ & & & & & & $\sqrt{ }$ & & 11 \\
\hline
\end{tabular}

Sumber: dokumen pribadi

Siswa yang ikut berpartisipasi dalam kegiatan ini berjumlah 35 orang. Sebanyak 15 siswa yang berjenis kelamin laki-laki dan 20 siswa berjenis kelamin perempuan (dapat dilihat pada Gambar 
1). Terdapat 5 anak yang berpendidikan TK, 6 orang siswa berpendidikan kelas 1 SD, 5 siswa kelas 2 dan 6 siswa kelas $3 \mathrm{SD}, 4$ siswa berpendidikan kelas 4 dan $5 \mathrm{SD}$, dan yang terakhir berpendidikan kelas 6 SD berjumlah 5 siswa. Rentang usia 8 dan 9 tahun mendominasi yaitu sebanyak 6 orang, kemudian disusul dengan rentang usia 7, 10 dan 12 tahun sebanyak 5 orang siswa. Usia 6 dan 11 tahun sebanyak 3 orang, kemudian yang terakhir usia 4 dan 5 tahun masing - masing hanya 1 orang siswa. Berikut merupakan grafik peserta MDR berdasarkan jenis kelamin.

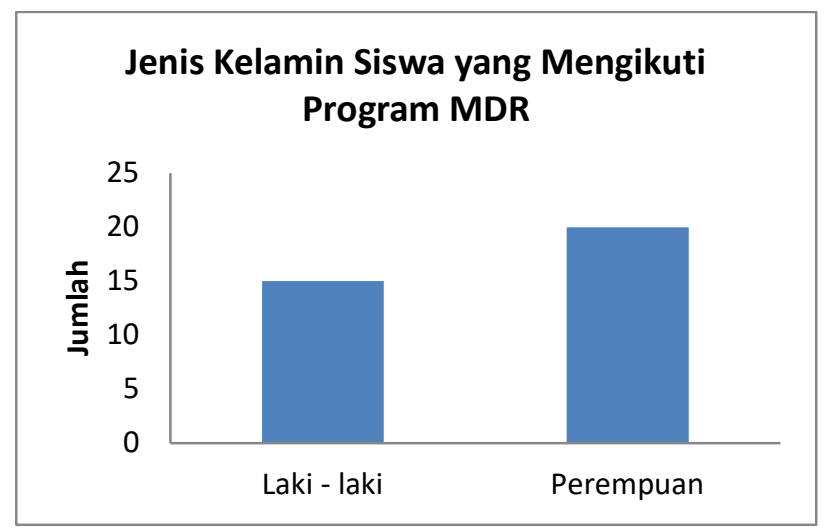

Gambar 1. Grafik Jenis Kelamin Siswa yang Mengikuti Program MDR

Tabel 2. Distribusi siswa yang mengikuti menurut tingkat pendidikan

\begin{tabular}{|c|c|c|}
\hline Tingkat Pendidikan & Jumlah & Presentasi (\%) \\
\hline TK & 5 & 14,28 \\
\hline 1 SD & 6 & 17,14 \\
\hline 2 SD & 5 & 14,28 \\
\hline 3 SD & 6 & 17,14 \\
\hline 4 SD & 4 & 11,42 \\
\hline 5 SD & 4 & 11,42 \\
\hline 6 SD & 5 & 14,28 \\
\hline Total & $\mathbf{3 5}$ & $\mathbf{1 0 0}$ \\
\hline
\end{tabular}

Distribusi siswa yang mengikuti menurut tingkat pendidikan mulai dari TK sebesar 14,28 \%, kelas 1 SD sebanyak 17,14\%, kelas 2 SD sebesar 14,28\%, kelas 3 SD sebesar 17,14\%, 4 SD sebesar 11,42\%, 5 SD sebesar 11,42\%, 6 SD sebesar 14,28\%. Kegiatan ini rutin dilakukan 3 kali dalam satu minggu dan setiap pertemuan berlangsung selama 60 menit. Pembelajaran ini memiliki kurikulum yang telah disiapkan oleh pemerintah Kementrian Pendidikan dan Kebudayaan, sehingga para pengajar mengikuti kurikulum yang ada (Rustandi, 2020). Selain itu, kegiatan ini juga membantu para siswa dalam mengatasi kesulitan belajar pada saat di sekolah dan membantu mengerjakan pekerjaan rumah yang diberikan oleh guru. Proses pada saat pembelajaran dapat dilihat pada Gambar 2. 


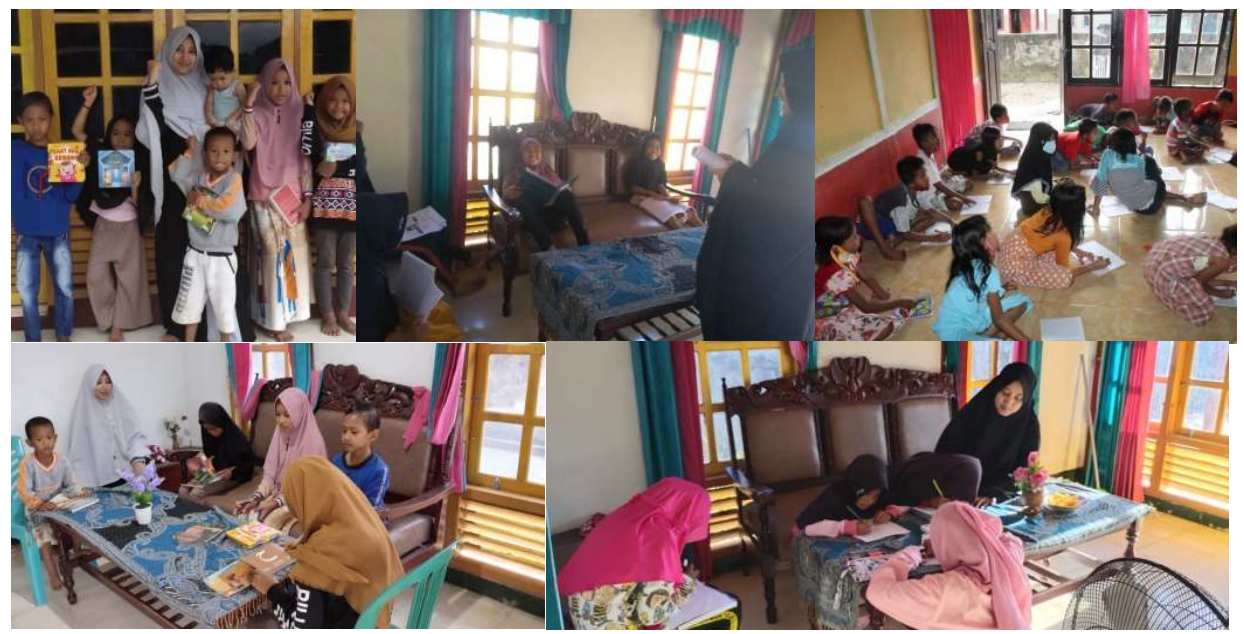

Gambar 2. Proses Belajar Mengajar dari Rumah

Analisis Statistik

Statistik selalu digunakan ketika parameter yang menggambarkan karakteristik populasi tidak diketahui. Statistik akan mengambil sebagian (kecil) dari populasi untuk dilakukan pengukuran, kemudian hasil pengukuran tersebut dijadikan sebagai kesimpulan terhadap keseluruhan populasi. Sebagian (kecil) dari populasi tersebut dinamakan sampel (Kusnadi, 2008). Penelitian ini menggunakan metode survei dan pengumpulan data menggunakan angket (kuesioner) yang telah disebar setelah kegiatan proses belajar mengajar ini berakhir. Kuesioner disebar di setiap orang tua siswa yang mengikuti kegiatan ini. Selain menyebarkan kuesioner penulis juga melakukan wawancara singkat terkait kegiatan program ini untuk melihat respon antusias masyarakat. Dalam wawancara singkat dengan setiap orang tua siswa terlihat semangat dan respon positif terhadap kegiatan ini. Akan tetapi, hal tersebut tidak cukup menjadi acuan peneliti untuk menyimpulkan hasil akhir, sehingga pengolahan data melalui kuesioner (angket) dianalisis. Hasil kuesioner dianalisis menggunakan statistik deskriptif dengan menggunakan program komputer SPSS, yaitu merupakan software powerfull yang digunakan untuk mencapai hasil yang akurat dalam analisis statistiknya. Berikut merupakan contoh kuesioner untuk orang tua siswa.

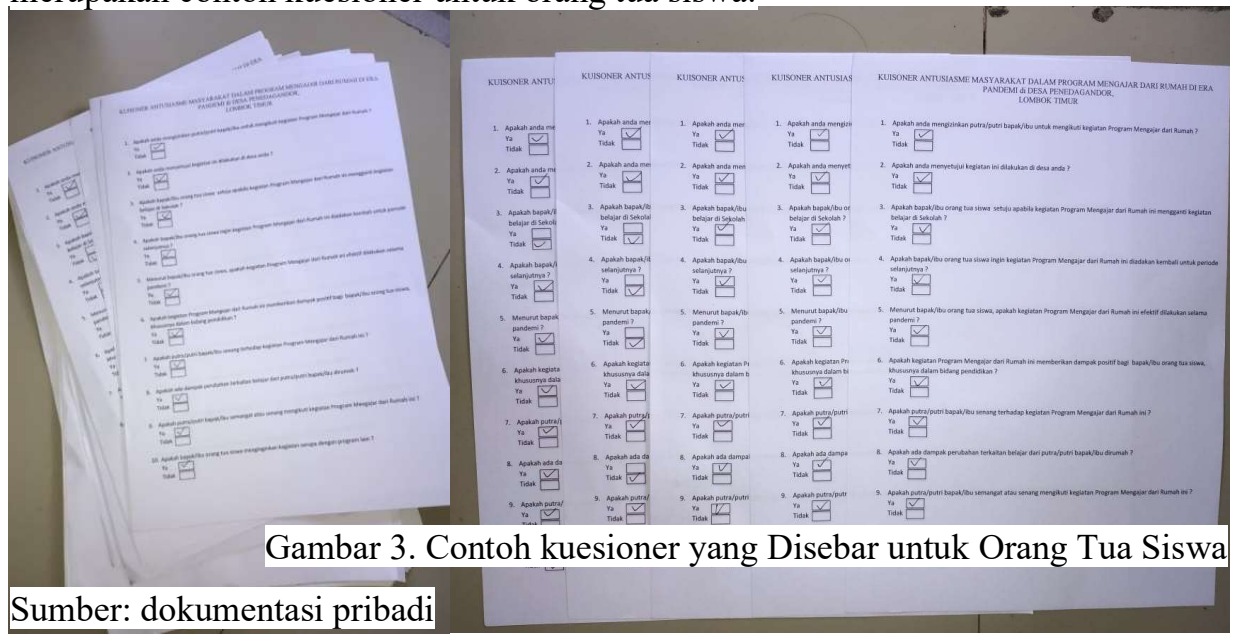


Contoh kuesioner yang telah disebar untuk orang tua siswa dapat dilihat pada Gambar 3. Kuesioner dibuat sangat sederhana agar orang tua siswa tidak kesulitan dalam mengisi daftar kuesioner. Penulis menyediakan 10 pertanyaan dalam kuesioner dan memberikan nilai serta range untuk setiap kategori. Nilai 90 -100 termasuk dalam kategori tinggi (sangat antusias), nilai $70-80$ termasuk dalam kategori sedang (antusias), nilai kurang dari 60 termasuk dalam kategori kurang antusias. Berdasarkan pengisian kuesioner hasil yang diperoleh adalah nilai 90 - 100 berjumlah 25 orang, nilai $70-80$ berjumlah 8 orang, nilai kurang dari 60 berjumlah 2 orang. Setelah didapatkan nilai range dan kategori dari kuesioner yang telah disebar, dilanjutkan dengan melakukan uji statistik menggunakan Program SPSS.

Tabel 3. Hasil Analisis Deskriptif Statistik

\begin{tabular}{|l|r|c|r|r|r|r|}
\hline \multicolumn{9}{|c|}{ Descriptive Statistics } \\
\hline & \multicolumn{1}{|c|}{$\mathrm{N}$} & \multicolumn{1}{c|}{ Mean } & \multicolumn{2}{c|}{ Skewness } & \multicolumn{2}{c|}{ Kurtosis } \\
\cline { 2 - 8 } & Statistic & Statistic & Statistic & \multicolumn{1}{c|}{ Std. Error } & Statistic & Std. Error \\
\hline HASIL KUESIONER & 35 & 90.57 & -1.168 & .398 & .502 & .778 \\
\hline Valid N (listwise) & 35 & & & & & \\
\hline
\end{tabular}

Terlihat Tabel Deskriptif Statistik yang terdiri dari nilai N, Mean, Skewness dan Kurtoisis. Dua Ukuran penting yang sering dipakai dalam pengambilan keputusan adalah: Yang pertama, mencari central tendency (kecenderungan memusat), seperti mean, median dan modus. Dan yang kedua mencari ukuran dispersion, seperti standar deviasi dan variasi. Selain central tendency dan dispersion, ukuran lain yang dipakai adalah Skewness dan Kurtosis yang berfungsi untuk mengetahui kemiringan data (gradien data) (Mousir, 2015). Untuk dapat menentukan hasil, yang perlu diperhatikan adalah nilai skewness dan kurtoisis.

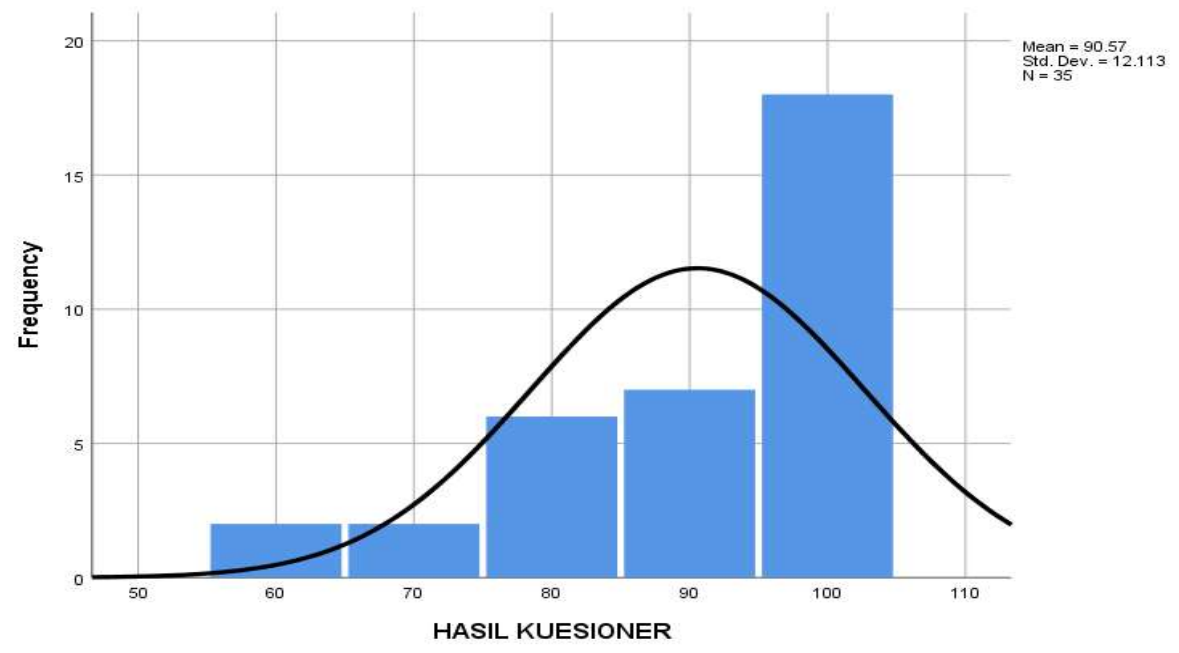

Gambar 4. Kurva Diagram Hasil Uji Statistik

Berdasarkan Tabel 3 di atas dapat dilihat nilai Skewness Statistics bernilai negatif dan Kurtosis Statistics bernilai positif. Nilai skewness statistik merupakan ukuran kesimetrisan histogram, 
sedangkan nilai kurtosis statistik merupakan ukuran datar atau runcingnya histogram. Idealnya nilai skewness dan kurtosis pada distribusi normal adalah nol. Oleh karena itu: Jika nilai skewness positif maka distribusi data "miring ke kiri distribusi normal" (ada frekuensi nilai yang tinggi di sebelah kiri titik tengah distribusi normal), sebaliknya apabila skewness negatif maka distribusi data "miring ke kanan distribusi normal".

Skewness merupakan kecondongan suatu kurva, dan kecondongan suatu kurva dapat dilihat dari perbedaan letak mean, median dan modusnya. Jika ketiga ukuran pemusatan data tersebut berada pada titik yang sama, maka dikatakan simetris atau data berdistribusi normal. Sedangkan jika tidak berarti data tidak simetris atau tidak berdistribusi normal. Ukuran kecondongan data terbagi atas tiga bagian,yaitu : (1) Kecondongan data ke arah kiri (ekornya condongkiri/negatif) di mana nilai modus lebih dari nilai mean(modus > mean); (2) Kecondongan data simetris (distribusi normal) di mananilai mean dan modus adalah sama (mean = modus); (3) Kecondongan data ke arah kanan (ekornya condongkanan/positif) di mana nilai mean lebih dari nilai modus(mean > modus) (Yunita, 2020). Sehingga, hasil analisis deskriptif statistik berdasarkan hasil kuesioner di atas, nilai N nya adalah 35 dan nilai mean nya 95,57. Kemudian untuk nilai Skewness Statistic -1.168 dan nilai Skewness Std. Error 0,398. Menurut Yunita (2020), untuk mencari nilai skewness juga dapat dihitung dengan menggunakan rumus Korelasi Mac Pearson, yaitu :

$$
\mathrm{Sk}=\frac{\pi-M o}{\sigma}
$$

Keterangan:

Sk : koefisien kecondongan

$\pi$ : nilai rata - rata hitung

Mo : nilai modus

$\sigma:$ standar deviasi

Sedangkan pengertian dari kurtosis atau keruncingan adalah tingkat kepuncakan dari sebuah distribusi yang biasanya diambil secara relatif terhadap suatu distribusi normal. Berdasarkan keruncingannya, kurva distribusi dapat dibedakan atas tiga macam, yaitu : (1) Leptokurtik, merupakan distribusi yang memiliki puncak relatif tinggi (nilai keruncingan $>3$ ); (2) Platikurtik, merupakan distribusi yang memiliki puncak hampir mendatar (nilaikeruncingan $<3$ ); (3) Mesokurtik, merupakan distribusi yang memiliki puncak sedang dan tidakmendatar (Normal (nilai keruncingan $=3$ ) (Yunita, 2020). Berdasarkan hasil analisis deskriptif statistik hasil yang diperoleh untuk nilai kurtosis statististiknya adalah 0,502 dan nilai Kurtosis Std. Error 0,778. Sehingga, dapat dikatakan bahwa kurtosis atau keruncingan dari data yang diperoleh merupakan jenis kurva Leptokurtik atau merupakan distribusi yang memiliki puncak relative tinggi, dimana nilai kurtosis dari data yang diperoleh adalah 0,502 . 
Dari data tersebut menunjukkan hasil skewness negatif, maka distribusi data "miring ke kanan distribusi normal" mengarah ke antusias masyarakat yang sangat tinggi. Kemudian, jika nilai kurtosis positif maka distribusi data "meruncing" (ada satu nilai yang mendominasi), sebaliknya apabila Kurtosis Negatif maka distribusi data "melandai" (varians besar). Dari data tersebut menunjukkan hasi kurtosis positif, maka distribusi "meruncing" (ada satu nilai yang mendominasi), meruncing kearah antusias masyarakat yang sangat tinggi. Apabila dilihat dari data yang telah diperoleh menggunakan uji statistik hasil yang diperoleh adalah nilai skewness statistic negatif dan nilai kurtoisis statistics positif yang berarti antusias masyarakat yang sangat tinggi. Kurva diagram hasil uji statistik dapat dilihat pada Gambar 4.

\section{Kesimpulan}

Berdasarkan hasil penelitian dengan melihat nilai statistik diatas dapat disimpulkan bahwa kegiatan Program Mengajar dari Rumah ini mendapatkan respon yang positif dan masyarakat sangat antusias terhadap kegiatan ini.

\section{Daftar Pustaka}

DISKOMINFOTIK NTB. 2020. Data Covid-19 NTB. https://corona.ntbprov.go.id. [01 November 2020]

Fahlevi, Fahdi. 2020. Kemendikbud Manfaatkan Program Mengajar dari Rumah untuk Sosialisasi Gerakan 3M. https://www.tribunnews.com/nasional/2020/10/16/kemendikbud-manfaatkanprogram-mengajar-dari-rumah-untuk-sosialisasi-gerakan-3m. [2 November 2020]

Harim, Sidiq. 2020. Metode Survey: Pengertian \& Proses Penelitiannya. http://sosiologis.com/metode-survey. [25 Oktober 2020]

Kasih, Ayunda Pininta. 2020. "Kemendikbud Luncurkan Program Mengajar dari Rumah".https://www.kompas.com/edu/read/2020/10/17/075526871/kemendikbud-luncurkanprogram-mengajar-dari-rumah. [2 November 2020]

Kusnadi, Eris. 2008. Statistik Deskriptif dengan SPSS. https://eriskusnadi.com/2008/12/11/statistikdeskriptif-dengan-spss/.

Mousir. 2015. Statistik Deskriptif Dengan SPSS. http://www.portal-statistik.com/2014/02/statistikdeskriptif-dengan-spss.html.

Rustandi, Dwi. 2020. Peluncuran Batch I Program Mengajar Dari Rumah dan Gerakan Mengubah Perilaku. http://dikti.kemdikbud.go.id/kabar-dikti/kabar/peluncuran-batch-i-program-mengajardari-rumah-dan-gerakan-mengubah-perilaku/. [3 November 2020]

Slamet, Y. 2006. Metode Penelitan Sosial. Surakarta: UNS Press.

Yunita, Ferdiana. 2020. Distribusi Normal, Skewness dan Qurtosis. Departemen Biostatistika FKM UI. Universitas Gunadarma. Depok. Jawa Barat 